\title{
Evaluation Model for the Level of Development of Work Organization System in Coal Mines
}

\author{
Koroleyva Tatiana G. ${ }^{\text {a }}$, Grigashkina Svetlana I. ${ }^{\text {b }}$ \\ T.F. Gorbachev Kuzbass State Technical University, \\ Kemerovo, Russian Federation \\ oekuzstu@mail.ru ${ }^{\text {a }}$,grigashkina_si@mail.ru ${ }^{\text {b }}$
}

\begin{abstract}
This article discusses the evaluation of the level of development of the work organization system in coal mines. It assumes that the key factor in the growth of labor productivity in the coal industry is the level of development of the system of work organisation. The model is proposed for the evaluation of the level of development of the system of work organisation in the company including three main indicators: results, costs, and time. The practical implication of this model allows to reveal the state of the system, to make recommendations for its amendment, to introduce them in activities, and to increase labour productivity. The present evaluation model has been used in the study of the existing system of work organisation in a coal mine of the Kemerovo region. Based on the results obtained, a list of system changes was developed to improve the organization of work of development sections at a coal mine which can be used as guidelines by other coal operations allowing to increase labour productivity of a development section by $20 \%$.
\end{abstract}

Keywords - work organisation system, labour productivity, labour remuneration, evaluation indicators and criteria, evaluation model for the level of development of work organisation system.

\section{INTRODUCTION}

The problem of ensuring the effective organization of labor in Russian coal mines is extremely acute and not integrated sufficiently into the overall strategy of the company development. As it is known, the organization of labor in coal mines is carried out under specific conditions of exposure to a number of technological, organizational, economic, and management factors. For coal mines, an increase in coal output is continuously connected with the use of modern techniques and technology. However, various mining geological and technical conditions in the coal mines, the low skill level of workers, non-compliance with the technical regulations of machinery operation do not provide high productivity, and this leads to unreasonable financial losses [1].

It is possible to get the maximum effect of the efficient work organisation on the condition of a complex solution of the problem, i.e. not only through implementation of technical measures but also bringing the existing work organisation in line with the level of the new equipment. If the level of work organisation does not correspond to the level of the new technology, this machinery is only a precondition for more efficient labour and by itself cannot provide the required rate of labor productivity growth. Therefore, there is a problem of objective evaluation of the work organisation system as a system factor of increase of labor productivity in the short term [2]. This evaluation will allow to describe the state of the system of work organisation and its level for the coal operation in general and its individual sections, and to determine the contribution of each section in the implementation of the planned task. Lack of theoretical study of this issue for the coal industry and at the same time its importance determine the relevance of the implemented research.

Work organisation and management were the issues studied by such foreign scholars as F. Taylor, Frank and Lillian Gilbert, Harold B. Maynard and D.L. Schwab, A.B. Segur, G. Emerson, E. Mayo, and others [3]. In Russia, the questions of the scientific work organisation have been studied by such prominent scientists as A.K. Gastev, A.A. Bogdanov, O.A. Yermansky, V.M. Joffe, P.M. Kerzhentsev, A.I. Roffe, and others [3].

The novelty of the work is in the fact that it gives the theoretical and practical justification for the systematic approach to evaluation of the level of a work organisation system development in the coal mines and provides the method of its calculation. A model has been developed for evaluation of the level of work organisation in the "indicatorsproperties-criteria" system and the areas for improvement of the system of work organisation in coal mines.

\section{SUBJECT OF RESEARCH}

The purpose of this study is to develop the model for evaluation of the level of development of the work organisation system in coal mines.

The objectives of the study:

- determine indicators of the model;

- identify the properties of the system and criteria of its evaluation;

- develop recommendations for improvement of work organisation in the coal mines.

The object of research is the system of work organisation in coal mines, which is an organisational and technical system, on the one hand, and a socio-economic system, on the other 
hand, presenting a complex system due to a combination of factors it is exposed to. Therefore, the systematic approach method was used in the study of the labor organization system in the coal mines.

\section{RESULTS AND DISCUSSIONS}

According to the forecast of the International Energy Agency, in the middle of this century coal will dominate in the global energy mix with the reserves which will last for six centuries. At the same time, coal accounts for about $90 \%$ of the energy potential of organic origin minerals suitable for industrial development. World energy consumption will increase by 1.4 times - up to 17.3 billion tons of equivalent fuel, including coal up to 5 billion tons of coal equivalent (by 1.5 times) [4].

The coal industry is an important part of the fuel and energy complex for the economy of Russia. As at 01.01.2016, 192 coal operations were mining coal in the Russian Federation including 71 coal underground mine and 121 open pit.

For the Russian coal industry, improvement of workers work organisation in coal mines is a priority objective since labour productivity of Russian miners was "in average about 2,000 tonnes per one employee per year (in 1990 coal output per one employee in the industry was about 500 tonnes, in 2000 - over 800 tonnes, in $2010-1,880$ tonnes, with the intention to bring this indicator to 9,000 tonnes by 2030) which is 5 times lower than the labour productivity in world developed coal producing countries (in the USA this indicator is 12,900 tonnes, in Western Europe - 10,000 tonnes)» [5].

We agree with the opinion of B.L. Lavrovsky that "the value of labor productivity, its dynamics are one of the most important, if not crucial, conditions to achieving ever higher levels of competitiveness of the socio-economic system, eventually - the quality of life. In other words, the higher labour productivity, the higher the quality of life" [6].

A significant part of the lag in labor productivity in the coal industry is due to inefficient work organization. We agree with the opinion of V.A. Makarova that "the growth of labor productivity is becoming the only way to simultaneously improve the competitiveness of enterprises and workers' living standards while reducing product wage-to-cost ratio. At the same time, the methods used do not allow to significantly increase productivity since they are focused primarily on logistical factors (acquisition and modernization of highperformance equipment, means of automation and mechanization of the labor process), without providing conditions for the development of social and labor relations of the company entities. This leads to a natural resistance of the workers to improvement of productivity" [7].

In this regard, it makes sense to develop the model for evaluation of the level of development of the work organisation system of coal mine employees.

Currently, in the theory there are three most widely recognized and spread main ways to evaluate the level of work organisation:
- by comparing with the total potential fund of the staff working time;

- through evaluation of different areas of work organisation by partial coefficients and calculation on their basis of the integrated general level of work organisation (methodology of the Labour Research Institute),

- by the data (workplace assessment).

It should be noted that in the scientific literature and in practice evaluation of work organisation as a system is not applied, and all the techniques presented were developed in the socialist conditions of the country development. Therefore, the results of research are aimed at further development of the theory and practice of the work organisation, at the increase in its effectiveness and role in the staff personnel management.

We can say that the organisation of work is an important factor in increasing the efficiency of any activity. We assume that the key factor in the growth of labor productivity in the coal industry is the level of development of the work organisation system. The objective function of the work organisation system is to achieve and maintain compliance with the technical level of production by ensuring coordination of all elements of the system.

The authors believe that there is a nonlinear relationship between the level of development of the work organisation system and labor efficiency. This means that the function of labour efficiency may look as follows $\mathrm{R}=\mathrm{f}(\mathrm{U})$.

In turn, to assess the level of development of the work organisation system in the company, a model is proposed that includes three basic indicators: results, costs and time. These indicators fully describe all the properties of the system of work organisation, have evaluation criterion and can be determined by an expert way in the range $0-1$, where 0 means the state does not meet the criteria, 1 - the state meets the criteria in full.

The indicators of the evaluation model in their relationship with the system properties and the evaluation indicators are shown in Table 1.

TABLE 1. Evaluation Model for the Level of Development of the Work Organisation at an Enterprise

\begin{tabular}{|l|l|l|}
\hline Model Indicator & System Properties & Evaluation Criterion \\
\hline \multirow{4}{*}{ 1.Result } & Capacity for work & $\begin{array}{l}\text { A degree of the } \\
\text { system compliance } \\
\text { with the technical } \\
\text { level of production }\end{array}$ \\
\cline { 2 - 3 } & Integrity & $\begin{array}{l}\text { A degree of } \\
\text { satisfaction of } \\
\text { requirements in } \\
\text { resources }\end{array}$ \\
\cline { 2 - 3 } & Sfficiency \\
\hline \multirow{3}{*}{ 3.Time } & Scale & $\begin{array}{l}\text { Prompt changes in } \\
\text { response to internal } \\
\text { and external impact }\end{array}$ \\
\cline { 2 - 2 } & Resource intensity & \\
\cline { 2 - 2 } & Balance & \\
\hline
\end{tabular}

Depending on combinations of the indicator values the following conditions of the system are possible: 
1. Optimal condition $-\{\operatorname{rmax}, \mathrm{zmin}, \mathrm{tmin}\}-$ is characterised by achievement of the maximum possible result at minimal resources and time;

2. Acceptable condition - $\{\operatorname{rmax}, \mathrm{zmax}, \mathrm{tmin}\}$ or $\{\operatorname{rmax}$, zmin, tmax $\}$ - is characterised by the need for extra resources or time in order to achieve the maximum result;

3. Limited acceptable condition $-\{$ rmin, zmin, tmin $\}$ or \{rmax, zmax, tmax $\}$ - is characterised by the disagreement of elements at which minimal resources and time allow to achieve only a minimal result, while the maximal result is possible only at maximal inputs. This state is allowed only in case of significant changes in the technical level of production, and only in the short term. In this state, the system reaches a bifurcation point and moves to a new quality.

4. Unacceptable condition - is characterised by a minimal result at the maximal input of resources and time in any combinations. This state indicates serious problems in the organisation of work and lack of coherence of the elements of the work organisation system.

The evaluation model for the level of development of the work organisation system has been applied in the analysis of the existing organisation of workers labour in the coal mine at Development section no.6 of of LLC Mine ChertinskayaKoksovaya by the main elements. The following results were obtained:

1.Organisation of Personnel Selection and Development.

1.1. Recruitment is carried out at an enterprise depending on the needs for personnel of a particular qualification. The condition of the labor market for such professions as a heading man and an electrician shows an excess of demand over supply that is why the selection of staff for development sections is reduced to assessing of compliance of the applicant to the requirements of the physical condition.

1.2. Retraining and advanced training of personnel. The company implements the traditional system of professional development in the context of areas of knowledge based on the educational training standards. There are neither professional standards, nor long-term programmes of professional development and retraining for the staff of development sections.

1.3. Personnel planning. Staff requirement is not planned. The Regulation on Personnel Reserve is in force.

2. Workplace Organisation.

2.1. Workplace facilities. No schedule of logistical materials supply. The system of planning stocks of materials in stock is not debugged. There is no regulation determining the material requirements. The composition of equipment is determined by the chart of a working, there is no description of its cost, time of service, and the technical condition.

2.2. Service of Workplace. It is implemented on a call from the place of production stop. There is a formal schedule of preventative maintenance. As a result, the number of fitters and maintenance workers has not been substantiated.

2.3. Working conditions. With regard to working conditions, only the established safety standards and working conditions in line with current legislation are provided. There is lack of staff motivation to safe and quality work.
3. Principles of work organisation.

3.1. Simplification of work processes. In the chart of a working, a general description of the process is given without breaking it down into simple operations.

3.2. Division of labor and cooperation. Division of labour prevails, more highly skilled workers perform low-skill work. There is a lack of the system of communication and engagement between the workers of one section and with other subdivisions.

3.3. Work balance. There is a lack of work schedule with break-down by separate operations (work sequence diagramme).

4. Work Planning and Rating.

4.1. Justification of work time standards and labor standards. Production rates and service standards do not take into account the specific nature of work. There are no current rules and regulations for the coal basin and the businesses.

4.2. Work planning and recording. Section work performance planning is carried out only by basic parameters, planned production cost is not specified by sections, headcount is estimated by obsolete labour standards, planned volumes of work are not justified. Work record considers only quantity.

4.3. Organisation of payment and material stimulation of work. The size of wage is linked to the monthly average job parameters, the size of the variable part is determined by the time worked without regard to the complexity and quality of work. Bonus system does not consider the end result of the company's activity.

Evaluation of the main elements of organisation of work at Development section 6 of LLC Mine Chertinskaya-Koksovaya has identified the following shortcomings:

- Low level of development of managerial skills;

- Inaccurate statement of the task, lack of control over the execution,

- Inconsistency of the grade of a worker with the work category;

- Cost overrun;

- Unjustified rates of service, norms of manpower;

- Down-time due to machinery failure, service on call;

- Low level of cooperation;

- Supply shortages;

- Low level of work concentration;

- High level of work division;

- Ineffective engagement with support services;

- Insufficient motivation to professional activity;

- No connection between payment and the end results of activity of the enterprise.

To eliminate the identified shortcomings, system changes are suggested shown below in Table 2 .

The proposed changes in the organisation of work for the workers of the Development section have been put into practice, as a result, the labor productivity increased by $20 \%$. 
TABLE 2 - System Changes in Work Organisation at Development Section no.6 of LLC Mine ChertinskayaKoksovaya

\begin{tabular}{|c|c|c|}
\hline Changes & Expected result & $\begin{array}{c}\text { Shortcomings to be } \\
\text { eliminated }\end{array}$ \\
\hline $\begin{array}{l}\text { Introduction of a modular } \\
\text { system of professional } \\
\text { development and retraining } \\
\text { based on the results of } \\
\text { evaluation of the level of } \\
\text { staff competencies } \\
\text { development and } \\
\text { competency profiling by job } \\
\text { positions }\end{array}$ & \begin{tabular}{|c|} 
Raising the levels of \\
competencies development, \\
justification of nomination \\
in the talent pool, \\
increasing efficiency of \\
decisions taken
\end{tabular} & $\begin{array}{c}\text { Low level of } \\
\text { development of } \\
\text { managerial } \\
\text { competencies, an } \\
\text { inaccurate } \\
\text { statement of tasks, } \\
\text { lack of control over } \\
\text { implementation }\end{array}$ \\
\hline $\begin{array}{c}\text { Introduction of the task card } \\
\text { as the main procedure for } \\
\text { work organisation of } \\
\text { Development sections }\end{array}$ & $\begin{array}{c}\text { A detailed description of all } \\
\text { types of work and } \\
\text { operations, reconciliation } \\
\text { of volumes, timelines and } \\
\text { costs for driving a heading, } \\
\text { justification of the plans }\end{array}$ & $\begin{array}{c}\text { Inconsistency of } \\
\text { the grade of a } \\
\text { worker with the } \\
\text { work category, cost } \\
\text { overrun, unjustified } \\
\text { rates of service, } \\
\text { norms of } \\
\text { manpower } \\
\end{array}$ \\
\hline $\begin{array}{l}\text { Changing the planned } \\
\text { preventive maintenance } \\
\text { procedure }\end{array}$ & $\begin{array}{c}\text { Preventive and prompt } \\
\text { maintenance, } \\
\text { implementation of planned } \\
\text { preventive maintenance } \\
\text { work }\end{array}$ & $\begin{array}{l}\text { Down-time due to } \\
\text { machinery failure, } \\
\text { service on call }\end{array}$ \\
\hline $\begin{array}{l}\text { Changing the procedure of } \\
\text { engagement with } \\
\text { neighbouring business units }\end{array}$ & $\begin{array}{c}\text { Establishing the system of } \\
\text { relationship and } \\
\text { engagement of the workers } \\
\text { in the section among } \\
\text { themselves and with other } \\
\text { units }\end{array}$ & $\begin{array}{c}\text { Low level of } \\
\text { cooperation; } \\
\text { supply shortages }\end{array}$ \\
\hline $\begin{array}{l}\text { Changing the structure of } \\
\text { personnel working in the } \\
\text { repair shift, increasing the } \\
\text { share of miners }\end{array}$ & $\begin{array}{l}\text { Reduced downtime for } \\
\text { equipment repairs and } \\
\text { maintenance during } \\
\text { production shifts, reduced } \\
\text { labor costs }\end{array}$ & $\begin{array}{c}\text { Low level of work } \\
\text { concentration, } \\
\text { unjustified rates of } \\
\text { service }\end{array}$ \\
\hline $\begin{array}{c}\text { Combining the professions } \\
\text { and expansion of service } \\
\text { areas }\end{array}$ & $\begin{array}{l}\text { During the repair shift } \\
\text { driving of heading is } \\
\text { performed, rate of driving } \\
\text { increases }\end{array}$ & $\begin{array}{c}\text { Low level of work } \\
\text { concentration, high } \\
\text { level of work } \\
\text { division }\end{array}$ \\
\hline $\begin{array}{c}\text { Implementation of } \\
\text { accounting and control } \\
\text { system }\end{array}$ & $\begin{array}{l}\text { Increasing the efficiency } \\
\text { and accuracy of } \\
\text { performance tasks } \\
\text { implementation, reduction } \\
\text { of downtime, increasing } \\
\text { motivation of workers }\end{array}$ & $\begin{array}{c}\text { Ineffective } \\
\text { engagement with } \\
\text { support services, } \\
\text { supplies shortages, } \\
\text { inaccurate } \\
\text { statement of the } \\
\text { task }\end{array}$ \\
\hline $\begin{array}{l}\text { Changing the regulation on } \\
\text { work remuneration and } \\
\text { incentives for employees }\end{array}$ & $\begin{array}{c}\text { Improving work quality, } \\
\text { improving staff motivation }\end{array}$ & \begin{tabular}{|c|} 
Insufficient \\
motivation to \\
professional \\
activity; No \\
connection between \\
payment and the \\
end results of \\
activity \\
\end{tabular} \\
\hline $\begin{array}{l}\text { Changing the procedure of } \\
\text { materials supply to the } \\
\text { section }\end{array}$ & $\begin{array}{c}\text { Timely provision of } \\
\text { development operations } \\
\text { with materials }\end{array}$ & $\begin{array}{l}\text { Supply shortages, } \\
\text { ineffective } \\
\text { engagement with } \\
\text { support services } \\
\end{array}$ \\
\hline
\end{tabular}

\section{CONCLUSION}

The main scientific and practical results of the study presented herewith are as follows:

1. The model indicators have been justified theoretically; the properties of the system and its evaluation criteria have been identified. The practical significance of the recommended model for assessing of the level of development of the system of work organisation is that by using it you can analyze the state of the work organisation and management, and also plan the level of organisation, and, consequently, encourage high performance productivity. The proposed model is based on the existing system of organisation of work in coal mines, and it does not require any significant changes and additions.

2. The proposed system of assessing the level of development of the work organisation system improves the operational efficiency of production management and provides the mechanism aimed at increasing of the productivity of labor.

3. The evaluation using the proposed model was performed and the shortcomings were identified in the main elements of the organisation of work at Development section 6 of LLC "Mine Chertinskaya-Koksovaya"; the recommendations were developed and their implementation allowed to increase labour productivity of the workers of the Development section by $20 \%$.

\section{REFERENCES}

[1] B.A. Kovalchuk, Economic evaluation of equipment upgrading options at coal mines: Thesis. ... PhD in economics: 08.00.05 - Economy and National Economy Management (economy, organisation, and management of enterprises, industry branches, complexes - industry) /Moscow State Mining University. - Moscow, 2004, p.112.

[2] A.M. Vdovichenko, Improvement of evaluation and analysis of the level of production and management organisation at mining enterprises: Thesis. ... PhD in economics: 08.00.05 - Economy and National Economy Management (economy, organisation, and management of enterprises, industry branches, complexes - industry) /G.V. Plekhanov Leningrad Mining Institute awarded the Order of Lenin, the Order of the October Revolution and the Order of the Red Banner of Labour. - Moscow, 1983. p. 140.

[3] O.A. Feoktistova, Development of the system of work standardization and stimulation as a mechanism of its quality improvement in the field of scientific research: Thesis. ... PhD in economics: 08.00.05 - Economy and National Economy Management (labour economics) /OJSC All-Russia Centre of Living Standard. - Moscow, 2014.- p. 260.

[4] O.V. Rogova, The state and prospects of development of the coal mining industry in Russia // Vestnik TSPU. - 2013. - \#12 (140). - pp. 99103.

[5] M.A. Komissarova, Strategic management of operations of the coal mining industry of Eastern Donbass: thesis. ... Dr. of Economic Sc.: 08.00.05 — Economy and National Economy Management: economy, organisation and management of enterprises, industry branches, complexes - industry/FGBOU VPO «Rostov State Economic University.Rostov-na-Donu, pp.2014.- 269.

[6] B.L. Lavrovskii, Russian and world trends in productivity. Studies on Russian Economic Development. May 2015, Volume 26, Issue 3, pp 278284.

[7] V.A. Makarova, Development of an organisational mechanism for an increase in labour productivity of workers at a mining operation: thesis. ... $\mathrm{PhD}$ in economics: 08.00.05 - Economics and national economy management (labour economics) / Research Scientific Institute of Efficiency and Safety in mining production.- Chelyabinsk, pp. 2014.127.

[8] Z.R. Geebadullin, F.H. Makshukov, F.I. Akshentsev, A.E. Triliev, Involvement of personnel in the improvement of work organisation at the Sibaisky underground ore mine // Vestnik of G.I. Nosov MSTU. - 2012. №3. - pp. 70-72.

[9] S.I. Zakharov, On the need to develop a system of work organisation and remuneration at mining enterprises // Vestnik of ChelSU. - 2014. №2 (331). - pp. 72-75. 
[10] M.L. Melnikov, L.A. Grachyova, Organisational and economic basics of production // Mining journal. - 2014. - \#6.

[11] Yu.V. Lakhno, The Russian coal industry: threats and opportunities of development // Forecasting problems. - 2015. - \# 05. - pp. 88-97.

[12] A.M. Solovev, Correlation of wage growth and labor productivity in military-industrial complex of Russia through 2020. Studies on Russian Economic Development. September 2014, Volume 25, Issue 5, pp. 478484.

[13] O.S. Smertin, E.V. Udovichenko, Management of innovation process of coal mining industry. 2003. - Ugol

[14] L.A. Shevchenko, The results of implementation of elements of corporate health and safety management in the coal industry of Kuzbass /
L.A. Shevchenko, I.L. Shevchenko // Vestnik Kuzbass. gosud. tehn. univ. - 2014. - \#2. - pp. 144-146.

[15] O.P. Chernikova, S.V. Strekalov, Reserves of labour productivity growth of coal mining operations employees // Mir nauki. - 2014. - \#3. pp. 1-12.

[16] L.V. Kalacheva, D.Yu. Savon, Features of high-efficient job place at innovation activity in coal industry // Humanitarian and social sciences. 2014 . - \# 6. - pp. 60-68.

[17] I.S. Magasumova, Specific features of the system and forms of work organisation at mining enterprises // Economics and politics. - 2012. - \#5 (5). - pp. 96-101. 